\title{
RECENZIÓ
}

DOI: $10.17165 / T P .2019 .3-4.19$

\section{A kétnyelvü nyelvi valóság komplex megismerésének útjai}

Tódor Erika Mária: Hétköznapi kétnyelvüség : nyelvhasználat, iskolai nyelvi tájkép és nyelvi én a romániai magyar iskolákban. Ráció Kiadó - Szépirodalmi Figyelő Alapítvány, Budapest, 2019. 251 p. ISBN 9789638798466

A „hétköznapi” címet viselő kötet a kétnyelvű lét olyan - legkevésbé sem hétköznapi - aspektusait tárgyalja, mint a nyelvi tájkép, a nyelvhasználati szokások vagy a nyelvi identitás, betekintést engedve a többnyelvü nyelvi valóság jelenségeibe. A sorok a kisebbségi lét életképeit, az egyén által megélt nyelvhez kötődő történeteket a környezet és a társadalmi-politikai közegbe ágyazva villantják fel.

A tanulmánykötet egy több szakaszból álló, öt évet felölelő empirikus kutatás eredményeinek összefoglalója. A szociolingvisztikai, alkalmazott nyelvészeti és nyelvpedagógiai írásokban a hangsúly a globális trendek lokális megnyilvánulásainak bemutatására helyeződik. A szerző kiemeli, hogy mivel a nyelv absztrakt rendszere nem vonatkoztatható el a gyakorlattól, kontextuális megértéséhez elengedhetetlen az interdiszciplináris megközelítés és annak fogalomtára, amely a fejlődő egyén nyelvi megnyilvánulásainak holisztikus megragadását teszi lehetővé. Az értelmezési keret szélesítését a nyelvi magatartás dinamikus volta, illetve digitális kommunikációba ágyazottsága is indokolja. A nyolc tanulmány ily módon lehetőséget kínál a kialakult aszimmetrikus kétnyelvü viselkedés értelmezésére, fókuszba helyezve az erdélyi magyarság iskolaszintű nyelvhasználatának jellegzetességeit az adatok tanulságai és a fejlesztési lehetőségek összefüggésében.

A kutatási téma dinamizmusa a módszerek szintjén is tetten érhető, hiszen alapegysége a multimodális szöveg (írott szöveg, képi anyag), melynek elemzése, értelmezése egy integrált kutatási modell megtervezésével történt. A kötet a nyelvi tájkép, valamint az iskolai nyelvi tájkép fogalmainak definiálásával indít, majd a romániai magyar tannyelvü iskolában betöltött szerepüket mutatja be a jelen és a közelmúlt vonatkozásában. A szerző ebben a térben helyezi el a személyiség nyelvi dimenziójának alakulását. A tanulmánykötet 
fejezetei az összegyüjtött adatok egy-egy részkérdését bontják ki.

A kötet fókuszában elsőként a nyelvi tájkép megismerése, kutatása áll. Lévén egy új alkalmazott nyelvészeti kutatási területről van szó, holisztikus megközelítése dinamikus kutatási paradigmák és módszerek integrált alkalmazását teszi szükségessé. A szerző kiemeli, hogy az oktatási intézmények vizuális nyelvhasználatának megfigyelése új keretet teremt a mindennapi létformák nyelvi dimenziójának értelmezéséhez, hiszen rávilágít a nyelvhasználat mögött rejlő nyelvi ideológiák, illetve a nyelvi hierarchia jelenlétére, felfedi az intézmény értékrendjét és egyúttal információval szolgál a tanárok és diákok önismeretéröl is.

A nyelvi tájkép kutatásának kiindulópontja a megfigyelés volt, mely során az iskolai környezetben látható elemek kerültek dokumentálásra. A megfigyelés elsődleges szempontjai, többek között, a jelen lévő nyelvek aránya, a nyelvi regiszterek megjelenési formái, a regionális nyelvi identitás sajátosságai és a rejtett tanterv voltak. Ezt követően került sor a diákokkal szervezett fókuszcsoportos beszélgetésre, illetve az iskolaigazgatókkal, tanárokkal, ügyintézőkkel készült szociolingvisztikai interjúkra, melyek tartalomelemzése a jelentősebb témakörök mentén történt.

Az iskolai nyelvi tájkép múltjának és jelenének feltárásáról szóló fejezetrészben az olvasó választ kap arra a kérdésre, hogy egy adott kor politikai, társadalmi jellemzői miként alakították az iskolai tér üzeneteit. Fény derül a pedagógusok vélekedésére az iskolai tárgyi környezetnek az oktatási kultúra kialakításában betöltött szerepét, valamint az iskolai vizuális nyelvhasználat jelenleg betöltött funkcióit illetően is.

A következő témakörben a nyelvi viselkedés és az énkép fogalom-meghatározásait követően a szerző felhívja a figyelmet a két- és többnyelvü egyén nem egynyelvü szemléletből történő megközelítésének jelentőségére, hiszen az egyén és élettere egy folyamatosan változó, vagyis dinamikus közegben alakul. Mivel a nyelvválasztási tapasztalatok ugyancsak visszahatnak az egyén identitásának alakulására, a nyelvi magatartásformák feltérképezése és kontextualizálása elengedhetetlen a holisztikus megértés érdekében. A nyelvhasználati tapasztalatokat érintő alfejezetben a szerző a nyelvi én három szimbolikus tere (család, közvetlen környezet és digitális kommunikáció) mentén vizsgálódik, s ez alapján mutatja be a minta kétilletve többnyelvü profiljait. A nyelvhasználatról szóló vélekedések feltárása során, az adott nyelvek a beszélők által hasznosnak illetve szépnek ítélt volta hozzásegít a nyelvi énkép érzelmi és értelmi dimenziójának árnyaltabb megismeréséhez, indirekt módon értékes információt szolgáltatva a jelenséggel szoros összefüggésben álló nyelvválasztásról és nyelvhasználatról. Az 
alfejezet további része a kutatásban a nyelvi viselkedés szempontjából olyan jellemzőnek vélt viselkedésformákat tár fel, mint a kommunikációs kudarc, a nyelvi lapszus, a nyelvi hiány, a kommunikációs szorongás vagy a nyelvközi tudatosság. A szerző kiemeli, hogy a második nyelvnek való kitettség nagymértékben befolyásolja a különböző nyelvi viselkedésformákat.

Az egyén szocializációjában ugyancsak kitüntetett helyen szerepel az iskola, melynek megválasztásával egyúttal identitásformáló életteret is választunk. A kötet ezen fejezete a romániai magyar tannyelvü iskolák osztálytermi nyelvhasználatának néhány sajátosságát mutatja be. Az első tanulmány az osztálytermi interakciók vonatkozásában külön figyelmet szentel a nyelvek elrendeződésének és előhívásának sajátosságaira, megkülönböztetve egynyelvü, célnyelv-domináns kétnyelvü vagy anyanyelv-domináns kétnyelvü osztálytermi interakciókat. Rávilágít továbbá arra is, hogy egyes nyelvhasználati jellemzők állandósult kapcsolatokká alakulhatnak, s ezek a nyelvi rutinok, amelyek állandó ismétlődésük folytán természetesebbnek tünnek, függetlenek a nyelvi környezettől. A fejezet második tanulmánya a 2011-ben történt tannyelvhasználati törvény módosításából adódó változásokkal, változtatásokkal foglalkozik. A törvény lehetővé tette az addig román nyelven oktatott Románia történelme és földrajza tantárgy magyar nyelvü oktatását, mely pedagógiai, módszertani és tannyelvhasználati módosításokat is eredményezett. A szaktanárok bevonásával, és meglátogatott tanórák tapasztalatai során a szerző arra a következtetésre jutott, hogy a tanárok több okból is lelkesedéssel fogadták a tannyelv-váltás lehetőségét. A történelem és földrajz tantárgyak anyanyelven tanítása egyfajta interpretáció is, tehát szimbolikus értékkel bír. A tannyelv-váltás lehetősége nem csupán nyitottabbá tette a tanárokat, és lehetőséget teremtett a gyakorlatias nyelvhasználatot, funkcionalitást szem előtt tartó szelektálásra, de önmegfigyelést is eredményezett. A reflexiók értékes információt szolgáltatnak a nyelvhasználók nyelvválasztási döntéseiről, világlátásáról, nyelvi értékítéletéről is. Ugyanakkor a szerző kihangsúlyozza, hogy a kétnyelvü létet jellemző olyan külső tényezők, mint a nyelvek elsajátításának módja, tárolása, a nyelvi környezet és a kommunikációs igény, nem hagyhatók figyelmen kívül a kétnyelvű egyén nyelvhasználatának megfigyelése során. A kettős nyelvü megnyilatkozások megítélését illetően arra a következtetésre jut, hogy bár a mindennapi nyelvhasználat során a beszélők a praktikumra és gazdaságosságra törekednek, legtöbbjük elutasítja a kódváltást.

Az utolsó fejezet olyan gyakorlatban alkalmazható kísérleteket és kezdeményezéseket mutat be, melyek a kutatási tapasz- 
talatok és dokumentált nyelvi valóság tükrében körvonalazódtak. E módszertani újítások bevezetése folytán a külső környezet vizuális nyelvhasználata az oktatás tárgyává válik. Az iskolai nyelvi tájkép (mint nyelvtanulási eszköz) lehetőségeinek felvázolását követően, a beszélt és írott nyelvi produkciók elemzése során kidolgozott eljárások kerülnek bemutatásra. A projektek kidolgozása egyetemi hallgatók, tanárjelöltek bevonásával történt ugyan, de a nyelvpedagógiai projekt kivételével, alkalmazásuk általános iskolai 7. és 8 . évfolyamos tanulók esetén is megvalósítható.

$\mathrm{Az}$ írások szakirodalmi alátámasztása sokoldalú, a legfrissebb tudományos munkákat is felvonultatja. A kötet végén az empirikus kutatás angol, illetve román nyelvü öszszefoglalója is megtalálható, elérhetővé téve azt az idegen nyelvü olvasóközönség számára is. A részleteiben gazdag képek, az áttekinthető táblázatok és ábrák, valamint a szemléltető példák tovább segítik a szerzői gondolatok követését, értelmezését.

Habár a tartalomjegyzék alapján a tanulmányok az említett három fó témakör köré csoportosulnak, ezek szoros összefüggése az olvasótól komplex látásmódot kíván. Kellő háttérismerettel azonban a tanulmányok önmagukban is olvashatóak, ezért a könyvet a téma szakértőin kívül haszonnal forgathatják a felsőoktatási intézmények nyelvszakos, tanár szakos hallgatói, gyakorló pedagógusok, valamint a jelenség dinamikáját mélységében megismerni vágyó egynyelvű nyelvfeldolgozásnyelvprodukció területén járatos szakemberek.

\section{SÁNTHA-MALOMSOKI ÁGNes ${ }^{1}$}

\footnotetext{
${ }^{1}$ PhD hallgató; Pannon Egyetem MFTK Többnyelvűségi Doktori Iskola; santha.m.agnes@gmail.com
} 